DOI: https://doi.org/10.32347/2077-3455.2021.61.159-169

УДК 719

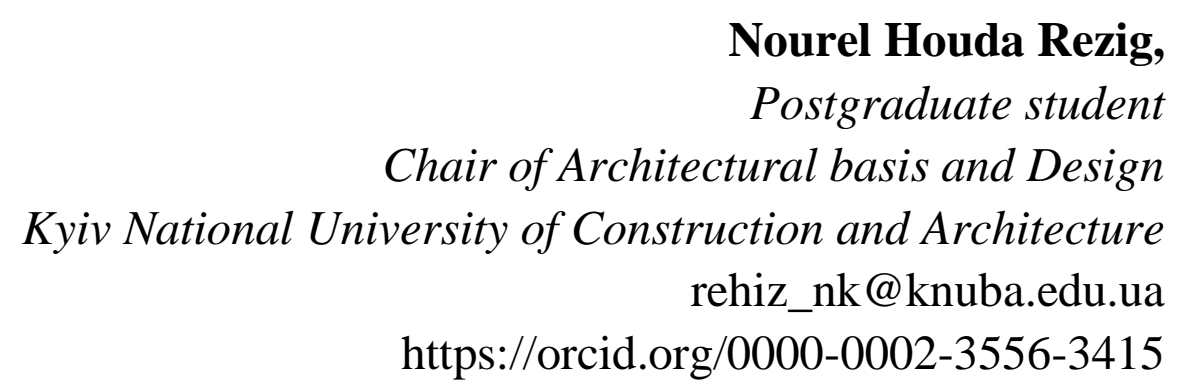

\title{
TRADITIONAL DWELLING OF M'ZAB VALLEY IN ALHERIA: THE POINT OF ADAPTATION TO THE ENVIREMENT
}

\begin{abstract}
UNESCO World Heritage ancient settlements (ksour) of M'zab Valley in Algerian desert. The Mozabite habitats are reflection of cultural and social values embodied in the architecture, with simple design in their forms deep in their indications, they are organized with a set of principles and rules known as customs that were inspired by religion and adapted to the environment. This latter helped to preserve Mozabite dwellings for more than a millennium. In this article the attention has been drawn to the dwelling's design and distribution of its spaces according the activities and lifestyle of Mozabite community considering the arid environment needs. Sustainability strategies have significant presence in different levels of the dwelling appearing from the usage of passive techniques which depend on the principles of conservation energy and water, exploiting renewable resources and usage of local materials. These techniques are what make dwellings integrate completely within arid climate.
\end{abstract}

Key words: M'zab Valley; Mozabite Architecture; Traditional dwellings; Climate adaptation; Sustainable Architecture; UNESCO World Heritage.

Introduction to the problem. The problem of the harmonization of dwelling with arid environment for existing in sustainability with it had obtained various decisions in traditional architecture of the world. One of the most interesting of them is the phenomenon of traditional habitat of UNESCO World Heritage M'Zab Valley fortified settlements (so called ksar or ksour in plural) existing for the millennium in the severe environment of Algerian desert [1].

The publications and researches of the problem. The traditional architecture of M'zab Valley in Algeria became the point of interest of many researches from the late 19th century. The most fundamental are the works of André Coyne [2], Amat Charles [3], Marcel Morand [4], Marcel Mercier [5], André Ravereau [6-7], Brahim 
Benyoucef [8] and many others. Nevertheless, the question of M'zab Valley's habitat sustainability could not be considered fully investigated every time allowing researches to analyse it from inattentive point.

The purpose of the article is to summarize the information about Mozabite habitat that help us to know more about the architectural heritage of Algeria. The providing a transparent knowledge of traditional dwellings' design principles within the arid region of M'zab Valley become the base for our future research. The conclusions of how those principles are based on cultural, social, religious values, as well as on sustainability with the environment might be useful not only for better understanding the traditional architectural heritage but also could serve as theoretical background for future architecture projects.

Local Dwellings of M'zab valley. M'zab valley's dwellings have been planned and structured basing on housing building traditions spread around the Mediterranean in general and in North Africa in particular, by relying on a mediated space and structuring the various spaces around it, in addition they are organised with a set of principles and rules that are reflected in design. All the houses, regardless of their size, share basic elements that differ in sizes slightly from one house to another, and these elements are distributed between the ground and upper floors, and rarely the basement [6-7].

The habitats in Valley of M'zab include the cultural and social values embodied in the architecture itself, with simple design in their forms, and deep in their indications, the principles of the design of the Mozabite houses are the central, the sanctity, the orientation, the hierarchy and the social solidarity [6, 9], (Figures 1-4).

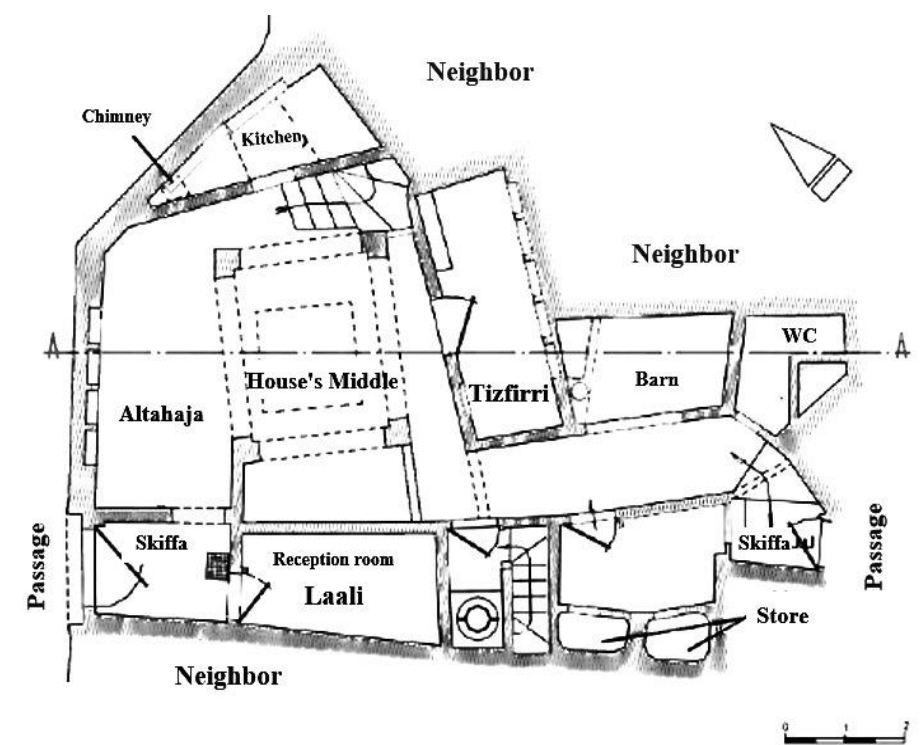

Fig 1: Plan of Ground floor of Mozabite Dwelling

(Source: The traditional dwelling: the architecture and custom of the protected sector in the M'zab Valley, www.opvm.dz, modified by Author) 


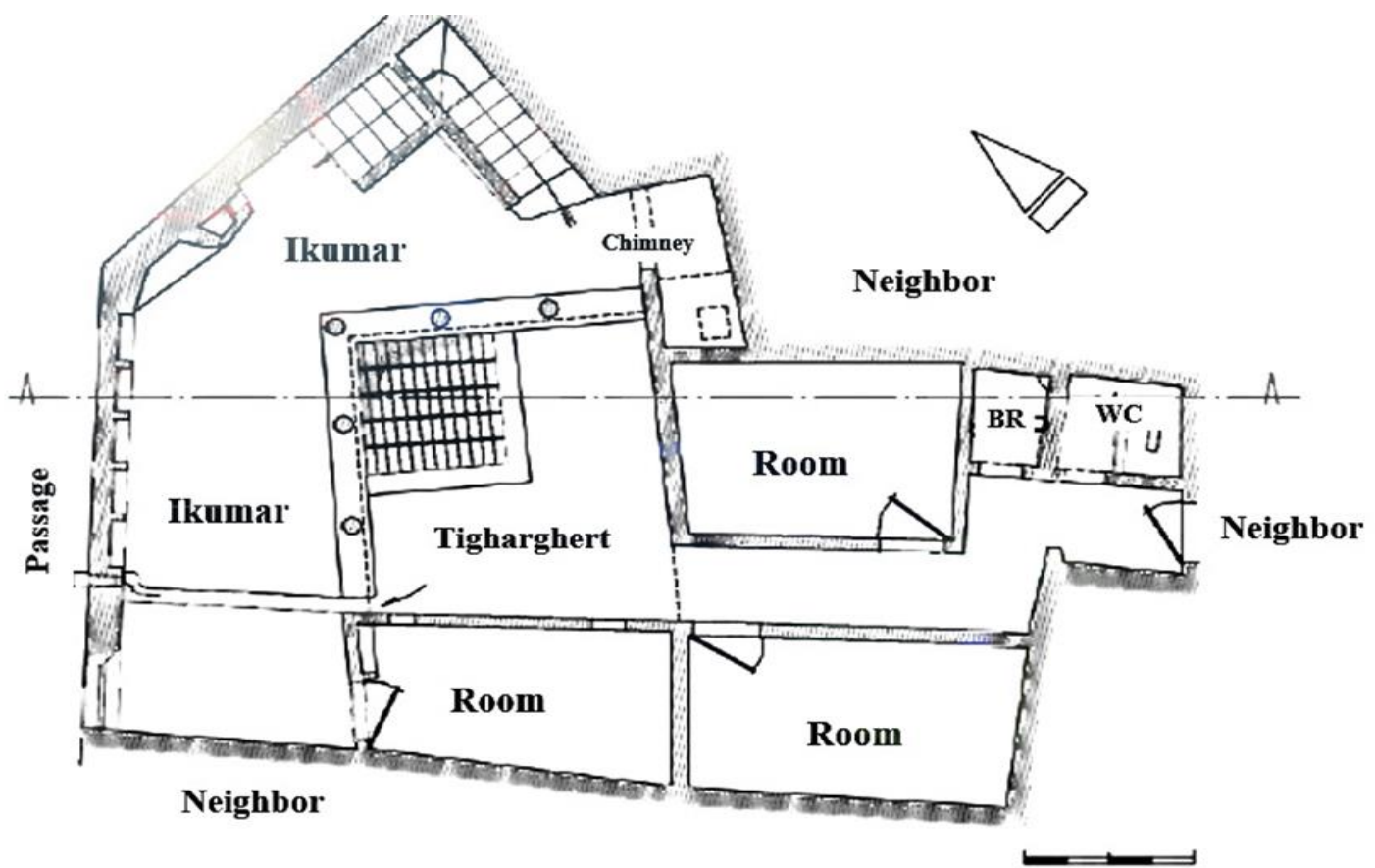

Fig 2: Plan of First floor of Mozabite Dwelling (Source: www.opvm.dz, modified by Author)

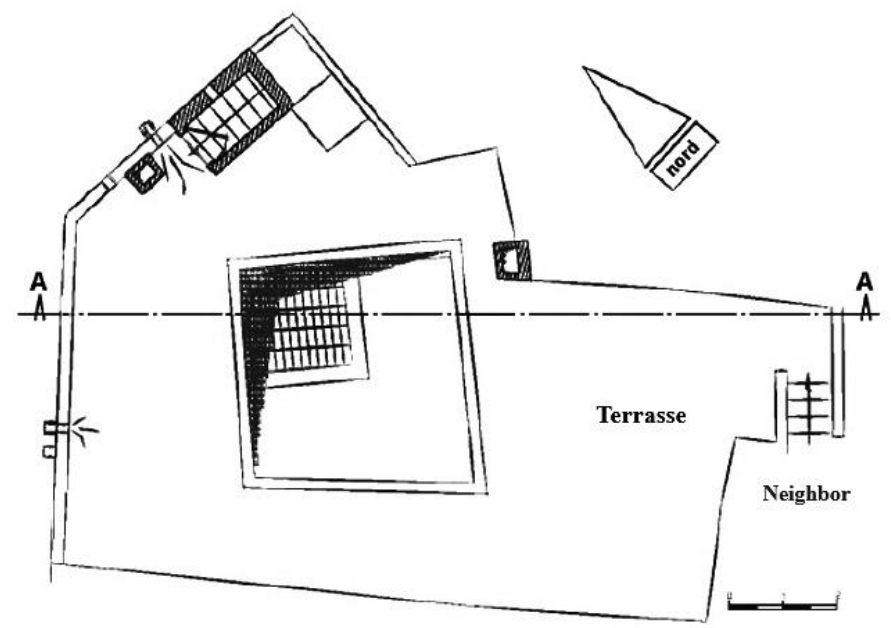

Fig 3: Plan of Terrace of Mozabite Dwelling (Source: www.opvm.dz, modified by Author)

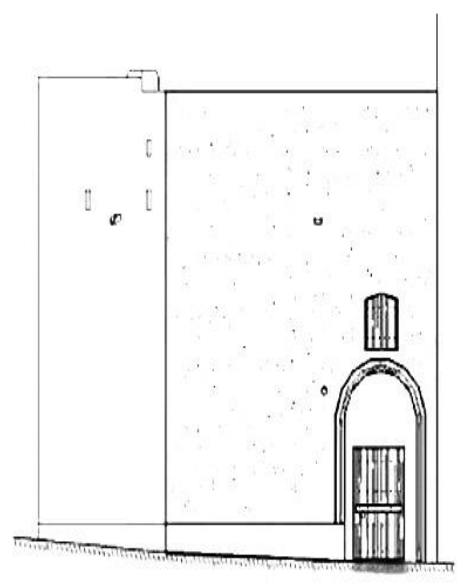

Facade

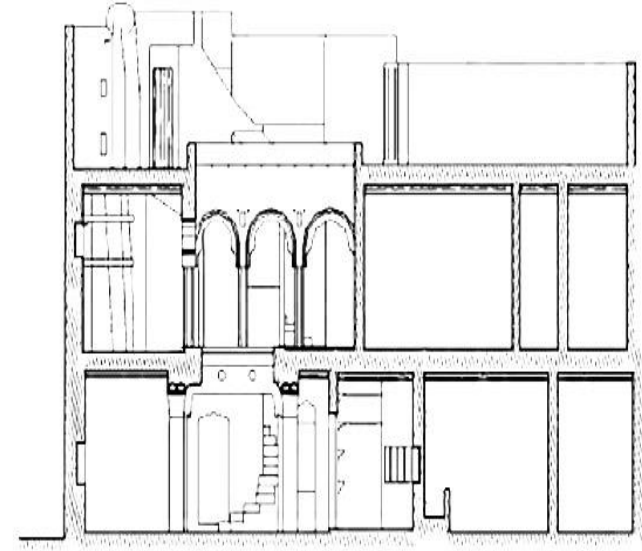

Section AA

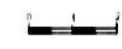

Fig 4: Façade and section of Mozabite Dwelling (Source: www.opvm.dz , modified by Author) (Source: www.opvm.dz, modified by Author) 
The components of Mozabite dwellings are as follows:

Skiffa: is an entrance part of the dwelling. It is located in the corner of the house, it is considered as a separator between the house and the outside by blocking the view and isolate sound between the inside and the outside of the house. And it also plays the role of waiting space for those who request permission to enter. The skiffa has an important climatic role, as it contributes to ventilating the house and protecting it from the infiltration of rainwater, cold air in the winter, and the spread of dust. It is also considered a barrier preventing the entry of reptiles and poisonous insects.

The hallway (altahjah): is a transitional space between the skiffa and the centre of the house, which is used to carry out some activities such as milling and weaving, and it is a suitable place for the animal to stand when unload of a firewood, agricultural crops, water, etc.

The reception room for men (laali): this room has a direct connection to the skiffa, it is intended only for men and isolated from the daily activity space for women, this space can be in ground or first floor, it has a second entrance that makes it in direct contact with the inside of the house.

The centre of the house: is considered the central and main space in the house in terms of its shape, dimensions, distribution, and structure for the various spaces around it, in addition. It is a semi-covered space with an opening window in the roof known as "shebak" that helps with lighting and ventilation.

The kitchen: there is no kitchen inside the Mozabite dwellings as a separate private space, but rather it is limited to a stove located in a corner of the centre of the house in such a way that the woman can monitor everything that happens inside the house and the entrance in particular.

The pantry room (store): is usually situated between the kitchen and the staircase ladder is a small room with wall niches for storing supplies and storing dates.

The rooms: the rooms in the traditional dwelling of the M'zab Valley are small in size. They do not have much use of furniture, but rather have built shelves, and wooden pieces are installed on the walls to hang clothes and things.

The reception room for women (tizfirri): is a room for women in which they meet and do their work, weave carpets and traditional textile products, the entrance is usually rather wide, and faces towards the qibla (the direction towards the Kaaba in Mecca Saudi Aribia used by Muslims during their religious rituals.) or the southwest to take advantage of more natural light

Rooftop gallery (ikumar): is a roofed space open to the roof by a series of arcs directed towards to the southwest and southeast to ensure optimal use of sunlight in the winter season, as this space is exposed to sunlight almost throughout the day and is also considered a transitional space between the rooms and the roof. 
The roof (tigharghert): is an open space located in the first floor, above the centre of the house, it provides lighting and ventilation for the house, the terrace gives a large space used all year during the days in winter and at night during the summer.

The facades: there are deaf facades devoid of ornate shapes and inscriptions, they are normal walls of equal height, and only wooden doors of the houses with some small openings in the upper floors appear on them [10, 11, 12].

Climate adaptation techniques of the Mozabite habitat could be grouped as follows:

Orientation: The mosque and most of the constructions within ksar are oriented towards the qibla and along the south-east, north-west axis.

The porticoes on the first floor are the most open to the outside so the most exposed to climatic conditions.

The southern facade of the house remains the best in orientation, it receives the most solar radiation during winter when the sun is low in the sky, penetrates deeply into the house, and heats it.

In summer the sun is high, so its perpendicular rays don't enter the interior of the house, the gallery "ikumar" is a protector whose role is to attenuate the intensity of the solar rays by the shade by providing comfortable circulation space.

The surface and the volumes: The reduction in the surface area of the house systematically leads to a reduction in temperature exchanges of interior and exterior. The Mozabite house does not generally exceed $100 \mathrm{~m}^{2}$ of the surface. Joint ownership and buildings density allow a minimum of heat loss in winter and a minimum of gain in summer.

Natural lighting: The outside openings of Mozabite dwelling do not exist practically as windows, they are small and located at the top of the walls. This practice is not justified only for intimacy reasons, but also to reduce the solar entries and minimize the surface of contact with the environment. The Mozabites use skylights in the way of transmission or distribution of natural light without being so exposed to sun rays.

Natural ventilation: Ventilation is so important in desert houses, it helps to refresh the spaces. Air circulation is activated thanks to the ingenious arrangement of openings and their dimensions. The openings must be opposite each other and the one by which the air enters must be smaller than the other which it exits.

It is known that at night the temperature goes down more than inside the dwelling. So to activate air circulation by the thermosiphon effect the position of the shebek (the opening window in the middle of the house) in the highest point allows rapid evacuation of hot air since it tends to rise unlike the cold air which descends. 
Another advantage of ventilation is the discharge of the energy collected in the walls, the latter being of high thermal inertia, it is advisable to ventilate them when the temperature is relatively low at night.

Humidity: The Mozabite didn't develop any techniques of humidification. During periods of the heatwave, occupants have jars of water placed in front of the air inlets. Water absorbs some of the heat from the air and moisturizes the atmosphere.

Materials: One of the characteristics that gave the M'zab Valley the sustainability and originality despite its simplicity is the use of all available local materials such as stones, sand, gypsum, palm's trunks and leaf, lime, etc. These materials not using only to ensure the integration of dwellings to the site and the general landscape of ksour, they guarantee also a concordance between the climate of desert and the thermo-physical properties of the material. They are fundamental elements of thermal comfort because they allow slowly transmission of the heatwaves inside the building while the temperature outside is decreasing.

Colours: The white dyes, pastel and light colours used in Mozabite houses are the best to adapt the climate. Because they reflect $100 \%$ of the sun's rays with minimal absorption rate. Besides, the light colours inside the dwelling assist the best distribution of light $[9,13,14,15]$.

Custom in traditional Architecture of valley M'zab. The early builders of M zab established ethnic rules and regulations for the Mozabite architecture inspired by Sharia "religion" and adapted to the environment. These rules are known as customs.

The customs helped to preserve settlements for more than a millennium, where the Mozabites were living in equality in all aspects. The committee of "Al'umana"' (this Arabic word means "The trustees") is the authority responsible for monitoring the implementation of customs in each ksar. The most important customs are:

- Respecting the general view of the settlement (ksar): by respecting the specific height of the house, which is 7.5 meters inside the ksar in order to not block the sun from the adjacent northern and eastern neighbour, also the number of floors in all buildings must be two-storied maximum.

- The height of the roof's walls on the first or upper floor should hide the residents from the neighbours' eyes.

- The exterior facades must be polished with sandy, white or cyan colour due to the characteristics of this colour which is adapted and integrated with the surrounding environment. It is also indispensable to shape protrusions creating small shaded areas.

- The house is has to be oriented towards the southeast and southwest, which enables to provide the minimum solar gain in summer, and the minimum thermal loss in the winter 
- If anyone wants to create a kitchen, a bathroom, or stairs, he must keep a distance of 3 arms from his neighbour.

- The shape of the house's windows, especially those overlooking the street directly, must be vertical not exceed $60 \mathrm{~cm}$ to reduce the leakage of hot air and sandy winds into the dwelling in order to preserve the thermal insulation and the sanctity of the house on the other side, and should not contain any type of decoration strange to the local architectural style.

- Drainage of water: it is not allowed to drain wastewater except for rainwater directly into the roads. Rather, every citizen must connect it to the sewage channels $[4,16,17]$.

The origin sources of the Mozabite architecture custom goes back to the thought of some ancient scholars of the M1zab Valley such as:

-The scholar Sheikh Abu al-Abbas Ahmad bin Muhammad bin Bakr al-Farsa'i, who set the jurisprudence of architecture in his famous synthesis Division and the assets of the lands (1111).

-The Diligence of the Jurists regarding what was agreed upon in the councils of Sheikh Saeed and Sheikh Abd al-Rahman al-Harthy during the sixteenth century.

-The thought of the scholar Sheikh Abd al-Aziz al-Thamili in his famous book The Nile and the Healing of sick (1808) and Sheikh Muhammad ibn Yusuf Atfaysh in his book Explanation of the Book of the Nile and the Healing of sick (1914).

- Al'umana's customs, which are written in the pamphlets for thousands of years about the System of water division inside the orchard and neighbourhood.

- The commandments of the Protection Office of the M'zab Valley.

-Decision No. 35/87 issued in the municipality of Ghardaia on 23 May 1967 related to respect the customs of traditional building within the historical M'zab settlements (ksour) and oases $[4,16]$.

Conclusions. To conclude, we can argue that the historical traditional of Mozabite dwellings are a real sample of millennium architecture and a true response to the community's needs and a direct reflection of their lifestyle and the requirements of the surrounding environment. These habitats showed different sustainable methods by using renewable resources such as natural lighting and ventilation where energy conservation is assured by using different techniques and the usage of available local materials which have a long life and consider as elements of thermal comfort. In addition, the social and religious building customs had contributed significantly to the organization of Mozabite constructions and the community.

This is what allowed Mozabite architecture to be a part of world heritage and a lesson of sustainability and originality and an excellent reference for nowadays architecture. 


\section{References}

1. Rezig Nourel houda. (2021). ANCIENT TRADITIONAL SETTLEMENTS IN ALGERIA: PENTAPOLIS OF M'ZAB VALLEY. Modern problems of architecture and urban planning, (60), 67-78. (in English). https://doi.org/10.32347/20773455.2021.60.67-78

2. André Coyne. (1879). Le Mzab. Typographie A. Jourdan. (in French).

3. Amat Charles. (1888). Le M'Zab Et Les M'Zabites. Challamel. (in French).

4. Marcel Morand. (1903). Les kanouns du Mzab. Typographie A. Jourdan. (in French).

5. Marcel Mercier. (1922). La civilisation urbaine au Mzab. Emile Pfister. (in French).

6. André Ravereau. (2003). Le Mzab, une leçon d'architecture. Arles: Actes SudSindbad. (in French).

7. André Ravereau. (2003). L'atelier du désert. PARENTHÈSES. (in French).

8. Brahim Benyoucef. (2018). Le M'zab: Regards d'urbanisme et de sociologie. Librinova. (in French).

9. A.Bouchair. A. Dupagne. (2003). Building traditional of M'zab facing the challenge of re-shaping its built form and its Society. Building and environment 38 P1345-1364. The University of Jijel. Algeria. The University of Liege. Belgium (in English).

10. Lalot Bahmad, Zabab Khudairhe, Baba Najjar Yunus. (2014). The traditional house: Architecture and custom in the protected sector of the M'zab Valley. Ghardaïa, Algeria. (in Arabic). http://www.opvm.dz/en/19_Brochures/110_traditional_house_(arabic_)/d

11. Baghbagha Abdel Aziz, Baba Najjar Yunus. Ksar Ghardaia. Ghardaïa, Algeria (in Arabic) http://www.opvm.dz/19_Brochures/171_Ksar_de_Ghardaia_Arabe_/d

12. Djelloul Zenati. (2018). Urban Development in the Heritage Cities, Wadi Mazab. KnE Engineering 3(4), pp. 405-424. DOI: 10.18502/keg.v3i4.2183 (in Arabic).

13. Nora GUELIANE, Karima HADDOUCHE. (2015). Revisit a Millennium heritage: energy performances of traditional Mozabite Habitat. International Seminar on Climate and Energy Engineering, SIGCLE. November 9, 10 and 11, 2015. Constantine, Algeria (in English).

14. A.Bouchair. (2004). The decline of an urban ecosystem of m'zab valley. Building and environment 39 P 719-732. The University of Jijel. Algeria. (in English).

15. N. Ebru Karabag. Nadjla Fellahi. (2019). Mzab Algeria vernacular architecture: a connection between the architecture and the environment. Conference 
Archdesign 16: III. International Architectural Design Conference on Design and Nature. July 2019. Izmir. Turkey (in English). https://www.researchgate.net/publication/334263768_MZAB_ALGERIAN_VERNA CULAR_ARCHITECTURE_A_CONNECTION_BETWEEN_THE_ARCHITECTU RE_AND_THE_ENVIRONMENT

16. Ramadan Kamal, Hamo Abdullah Al-Hajj, Baba Najjar Yunus. Custom in traditional construction valley M'zab. Ghardaïa, Algeria (in Arabic). http://www.opvm.dz/en/19_Brochures/34_Custom_in_traditional_construction_valle y_M\%E2\%80\%99zab_(Arab)/d

17. Djelloul Zenati. Abderrazak Zeggar. (2013). Elements of urban identity in the M'zab Valley. The Third National Architectural Heritage Forum. Medina. Saudi Arabia.

December

2013. https://www.researchgate.net/publication/325439084_nasr_alhwyt_almranyt_fydy_

Аннотация

Ноурэль хоуда Резиг, аспирантка кафедры Основ архитектуры и архитектурного проектирования, Киевский национальный университет строительства и архитектуры.

\section{Традиционное жилище долины М'заб в Алжире: аспект адаптации к окружающей среде}

В статье рассматриваются традиционные жилища внесенных в список всемирного наследия ЮНЕСКО древних поселений (ксур) долины М заб в пустыне Алжира. Жилище Мозабитов является отражением культурных и социальных ценностей их общества, воплощенных в архитектуре простой по форме, но глубокой по содержанию. Эта архитектура сформировалось благодаря набору правил, известных как «обычаи», которые были выработаны на основе религии и принципов адаптации к окружающей среде, что помогло сохранить жилища Мозабитов более тысячелетия. В статье уделено внимание особенностям архитектурного дизайна и планировки жилища в соответствии с деятельностью и образом жизни общины Мозабитов и учетом необходимости приспособления к засушливой среде. Стратегии устойчивого развития просматриваются на разных уровнях организации жилища, возникая в связи с использованием пассивных адаптационных методов, основанных на принципах сохранения энергии и воды, возобновляемых ресурсов и местных материалов, что позволяет жилью полностью приспособится к местному засушливому климату.

Ключевые слова: долина М'заб; архитектура Мозабитов; традиционное жилище; адаптация к климату; архитектура устойчивого развития; Всемирное Наследие ЮНЕСКО. 
Анотація

Ноурель хоуда Резіг, аспірантка кафедри Основ архітектури i архітектурного проектування, Київський національний університет будівництва і архітектури.

Традиційне житло долини М'заб в Алжирі: аспект адаптації до

\section{навколишнього середовища}

У статті розглядається традиційне житло внесених до списку всесвітньої спадщини ЮНЕСКО древніх поселень (ксур) долини М’заб в пустелі Алжиру. Житло Мозабітів $є$ відображенням культурних і соціальних цінностей їх суспільства, втілених в архітектурі простий за формою, проте глибокій за змістом. Ця архітектура сформувалося завдяки набору правил, відомих як «звичаї», які були вироблені на основі релігії і принципів адаптації до навколишнього середовища, що допомогло зберегти житла Мозабітів понад тисячоліття. У статті приділено увагу особливостям архітектурного дизайну і планування житла відповідно до діяльності і способу життя громади Мозабітів 3 урахуванням необхідності пристосування до посушливого середовища. Зокрема, докладно розглянуто поперхову систему планування та склад приміщень типового для поселень долини М'заб житла, надані адаптовані пояснення місцевої термінології у назвах окремих житлових приміщень та архітектурних деталей специфічного призначення. Надалі, докладно розглянуто особливості пристосування архітектури житла Мозабітів до клімату пустелі, акцентовано увагу на усталених сторіччями системах інсоляції, вентиляції та зволоження традиційних помешкань, які працюють в даному випадку переважно за рахунок специфіки їх архітектурної форми та планування. Наприкінці роботи коротко окреслено специфіку традиційних законів співіснування Мозабитів, так званих «звичаєв», які торкаються аспектів забудови, регламентуючи не тільки розмір та поверховість, але й форму і навіть колір будівель. В результаті стає зрозуміло, що стратегії сталого розвитку проглядаються на різних рівнях організації жител долини М'заб, виникаючи у зв'язку 3 використанням пасивних адаптаційних методів, заснованих на принципах збереження енергії і води, поновлюваних ресурсів i місцевих матеріалів, що дозволяє житлу Мозабітів повністю пристосуватися до місцевого посушливого клімату.

Ключові слова: долина М'заб; архітектура Мозабітів; традиційне житло; адаптація до клімату; Архітектура стійкого розвитку; Світова Спадщина ЮНЕСКО. 